\title{
ANALISA RASIO PARKIR MOBIL UNTUK KANTOR SWASTA DI JAKARTA
}

\author{
Michael Tedja \\ Architecture Department, Faculty of Engineering, Binus University \\ Jl. K.H. Syahdan No. 9, Palmerah, Jakarta Barat 11480 \\ michaeltedja@gmail.com
}

\begin{abstract}
Jakarta's economy grew rapidly accompanied by the rapid growth of private office buildings in different areas of the city. This condition causes the need for car parking facilities at any existing private office buildings. Given the past 20 years, the Jakarta administration has never revised standard parking requirement in Jakarta. It causes the need be reviewed, to the extent appropriate parking ratio for a private office in the current period. This research is carried out on a number of park buildings at offices in Jakarta, the lower and upper limits of the implementation, then compared to the city standard parking. The results showed that the ratio standard park in Jakarta is no longer eligible based on the facts found.
\end{abstract}

Keywords: car parking ratio, office building, Jakarta

\begin{abstract}
ABSTRAK
Perekonomian Jakarta tumbuh dengan pesatnya diiringi juga dengan pesatnya pertumbuhan gedung perkantoran swasta di berbagai wilayah kota Jakarta. Kondisi ini menyebabkan perlunya fasilitas parkir mobil pada setiap gedung perkantoran swasta yang ada. Mengingat sejak 20 tahun terakhir, pemerintah DKI Jakarta tidak pernah merevisi standar kebutuhan parkir di Jakarta, perlu ditelaah kembali sejauh mana rasio parkir yang layak untuk suatu kantor swasta pada kurun waktu sekarang. Penelitian dilakukan terhadap sejumlah bangunan parkir di gedung perkantoran di Jakarta, batasan bawah dan atas dari penerapannya, kemudian membandingkannya dengan standar parkir di kota Jakarta. Hasil menunjukkan bahwa standar rasio parkir di Jakarta sudah tidak memenuhi syarat lagi berdasarkan fakta-fakta yang ditemukan.
\end{abstract}

Kata kunci: rasio parkir mobil, gedung perkantoran, Jakarta 


\section{PENDAHULUAN}

Kantor adalah tempat dilakukannya kegiatan pelaksanaan organisasi profit ataupun non profit untuk mencapai tujuannya. Pada dekade ini, kantor mempunyai makna lebih dari hanya sebagai tempat usaha, baik usaha dagang maupun usaha jasa, melainkan juga sebagai pusat kegiatan penyediaan dan penyebaran informasi.

Mengingat sulitnya transportasi umum di Jakarta, menyebabkan hampir semua orang yang perekonomiannya cukup, pasti memiliki kendaraan pribadi untuk bekerja, dengan jenis kendaraan sesuai kemampuannya.

Jumlah mobil di Jakarta yang terus meningkat, diiringi juga dengan meningkatnya orang yang dating ke perkantoran terus meningkat, baik sebagai penyewa maupun sebagai tamu, menyebabkan perlunya disediakan jumlah kebutuhan parkir yang cukup, sehingga para calon penyewa tertarik untuk menyewa gedung perkantoran tersebut.

Kebutuhan jumlah parkir mobil, akan berpengaruh secara signifikan terhadap kebutuhan jumlah luasan area parkir, baik itu parkir di dalam gedung, mapun parkir di halaman yang masih tersedia sebagai area terbuka (O’Flaherty, 1997).

Di Jakarta, penggunaan on street parking, atau parkir di tepi jalan, saat ini sudah hampir tidak memungkinkan lagi di daerah bisnis ataupun di daerah pusat perkantoran, bukan hanya keterbatasan lokasi tepian jalan, namun juga sudah diberlakukannya larangan parkir di tepian jalan oleh pemerintah daerah DKI Jakarta, baik itu secara permanen, ataupun hanya berlaku pada jam tertentu (Mia Layn Birk dan Christopher Zegras, 1993).

Kecenderungan harga tanah di Jakarta yang terus making tinggi, jauh lebih tinggi dibandingkan biaya konstruksi pembuatan gedung parkir, menyebabkan para pemilik perkantoran swasta lebih memilih membangun gedung parkir bertingkat banyak, dibandingkan menyediakan lokasi parkir di atas tanah langsung. Pembangunan gedung parkir ini dapat dilakukan di atas tanah maupun di bawah tanah.

\section{METODE}

Metode yang digunakan adalah membandingkan standar parkir yang sesuai dengan landasan teori yang ada, ataupun terhadap Peraturan Pemerintah Daerah setempat, serta membandingkannya dengan implementasi yang diterapkan pada berbagai bangunan perkantoran di Jakarta.

Peraturan perparkiran di Indonesia mengacu kepada Undang-undang no 14 tahun 1992 pasal 11 ayat 2, yang menyebutkan bahwa fasilitas parkir untuk umum dapat diselenggarakan oleh pemerintah, badan hukum Indonesia, ataupun warga Negara Indonesia. Dalam peraturan Menteri Perhubungan no 66 tahun 1993 pasal 7 ayat 2 mengatakan bahwa ijin penyelenggaraan fasilitas parkir untuk umum diberikan oleh bupati/walikota sebagai kepala daerah tingkat II.

Standar parkir yang akan dibahas pada bagian ini adalah untuk kendaraan mobil penumpang biasa, yang umum digunakan untuk penyewa, pengelola ataupun pengunjung perkantoran, yang datang ke lokasi perkantoran tersebut. Berdasarkan jenis kendaraannya, kebutuhan luasan yang diperlukan yaitu (Tabel 1, Ernest and Neufert, 2002): 
Tabel 1Standar Ukuran Kendaraan

\begin{tabular}{lcr}
\hline Jenis kendaraan & Panjang & Lebar \\
\hline Standar & 4,70 & 1,75 \\
\hline Kecil & 3,60 & 1,6 \\
\hline Besar & 5,00 & 1,9 \\
\hline
\end{tabular}

Dari tabel di atas, diambil ukuran yang paling cocok untuk kendaraan di Indonesia yaitu dengan jenis kendaraan besar, dengan panjang 5 meter dan lebar kendaraan 1,9 meter.

Berdasarkan standar ukuran tersebut, didapat ukuran dan luas kebutuhan parkir sesuai dengan bentuk parkir menjadi sebagai berikut (Tabel 2):

Tabel 2 Standar Kebutuhan Luasan Area Parkir

\begin{tabular}{lcc}
\multicolumn{1}{c}{ Bentuk parkir } & Luasan & Jumlah mobil per $\mathbf{1 0 0} \mathbf{~ m 2}$ \\
\hline Serong $30^{0}$ & 26,3 & 3,8 \\
\hline Serong $45^{0}$ & 20,3 & 4,9 \\
\hline Serong $60^{0}$ & 19,2 & 5,2 \\
\hline Tegak lurus $90^{0}$, lebar 2,5m & 19,4 & 5,1 \\
\hline Tegak lurus $90^{\circ}$, lebar 2,3m & 19,2 & 5,2 \\
\hline
\end{tabular}

Dari tabel di atas, terlihat bahwa bentuk yang paling optimal terhadap penggunaan lahan parkir adalah bentuk parkir dengan sudut serong $60^{\circ}$, atau bentuk parkir tegak lurus $90^{\circ}$, dengan lebar area parkir 2,3 meter, dengan kapasitas parkir per $100 \mathrm{~m} 2$ sebesar 5,2 mobil, atau rata-rata untuk 1 mobil membutuhkan area parkir dan sirkulasinya sebesar 19,23 m2.

Ukuran parkir tersebut hanya dapat digunakan untuk parkir di tempat terbuka, yang bebas dari kolom bangunan ataupun penghalang apapun yang dapat menyita luasan lantai parkir.

Mengingat besarnya kebutuhan jumlah parkir di suatu gedung perkantoran swasta bertingkat tinggi, cenderung kebutuhan area parkirpun tidak hanya cukup 1 lantai parkir. Sehubungan dengan perlunya direncanakan disain gedung parkir berlapis banyak (O'Flaherty, 1997), beberapa hal yang perlu diperhatikan yaitu: (1) jenis dan kemiringan ramp sangat berpengaruh pada penataan parkir. Kemiringan ramp yang digunakan umumnya antara $10 \%$ - 12\%, sedangkan batas maksimum ramp adalah 15\% (AASHTO, 1992); (2) ketinggian antar lantai (floor to floor), berkisar antara 3,05 m (Shenton Hill, J. D, dan Jarrold, 1990); (3) tinggi bebas (vertical clearance), berkisar antara 2,13m (Shenton Hill, J. D, dan Jarrold, 1990); (4) jarak antar kolom, dari segi perhitungan struktur, jarak antar kolom di area parkir kurang dari 10 meter, atau 3 buah mobil. Dengan jarak antar 2 kolom dapat menampiung 3 mobil, serta lebar parkir 2,3 meter, serta ukuran lebar kolom maksimal adalah 1 meter, maka didapat jarak as kolom ke kolom ideal adalah: $(3 \times 2,3 \mathrm{~m})+1 \mathrm{~m}=7,9 \mathrm{~m}$. Berkaitan dengan modul, maka modul ideal bangunan idealnya adalah $30 \mathrm{~cm}$, maka dari ukuran 7,9 meter dibulatkan ke kelipatan $30 \mathrm{~cm}$ sehingga menjadi 8,1 meter.

\section{HASIL DAN PEMBAHASAN}

\section{Studi Kasus Kebutuhan Parkir pada Bakrie Tower}


Luas lahan

Luas lantai dasar

Total area perkantoran

Total area sewa

Jumlah lantai

Jumlah lantai bawah tanah

Jumlah luas lantai bawah tanah
: $12.451 \mathrm{~m} 2$

: $1.591 \mathrm{~m} 2$

: 76,202 m2

: 59,404.96 $\mathrm{m}^{2}$

: 52 lantai.

: 4 lantai.

: $34,374 \mathrm{~m}^{2}$.

Denah basement dapat terlihat pada Gambar 1.

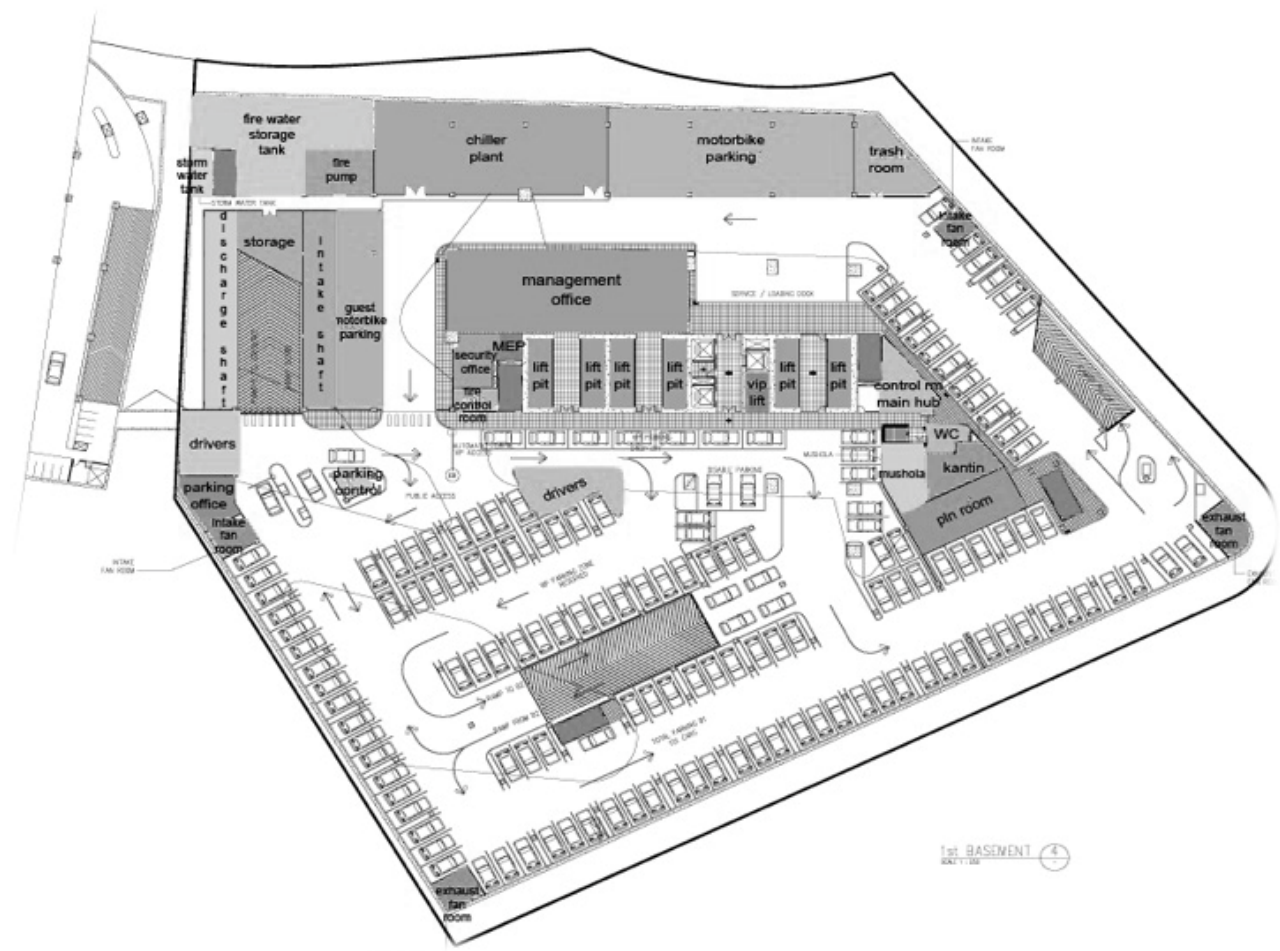

Gambar 1 Denah lantai basement bakrie tower

Pada gambar di atas tampak basement 1, dan pada area tersebut terdapat bukan hanya parkir, namun juga area sirkulasi vertikal untuk tangga kebakaran maupun lift, serta ruangan untuk utilitas yang mencapai 49\% dari total luas basement 1 tersebut.

Selanjutnya, denah basement 2 dapat dilihat pada Gambar2. Pada denah basement 2 terlihat bahwa area parkir makin besar, sementara area untuk sirkulasi dan utilitas tinggal 25\% dari luas total lantai basement 2. Berikutnya, denah basement 3 dapat dilihat pada Gambar 3.

Pada denah basement 3, terlihat luas lantai sirkulasi dan lantai utilitas sama seperti lantai basement 3 yaitu 25\% dari luas lantai basement 3. Terakhir adalah denah basement 4 yang dapat dilihat pada Gambar 4.

Pada denah basement 4 di atas, area sirkulasi vertikal dan utilitas yang hanya tinggal 6\% dari total luas lantai basement 4. Gambar 5 dibawah ini memperlihatkan posisi basement terhadap gedung perkantoran itu sendiri. 


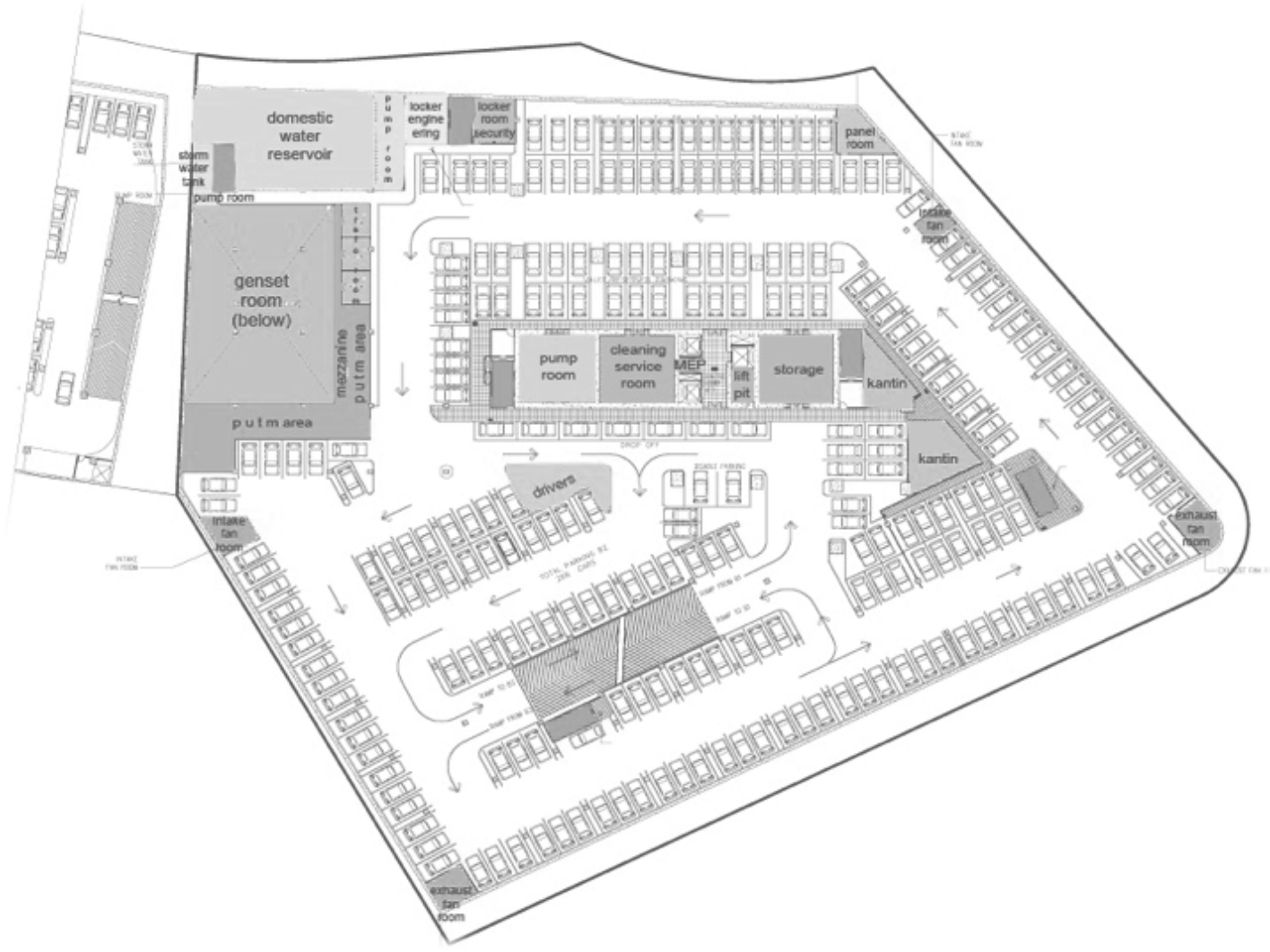

Gambar 2 Denah lantai basement 2 Bakrie Tower

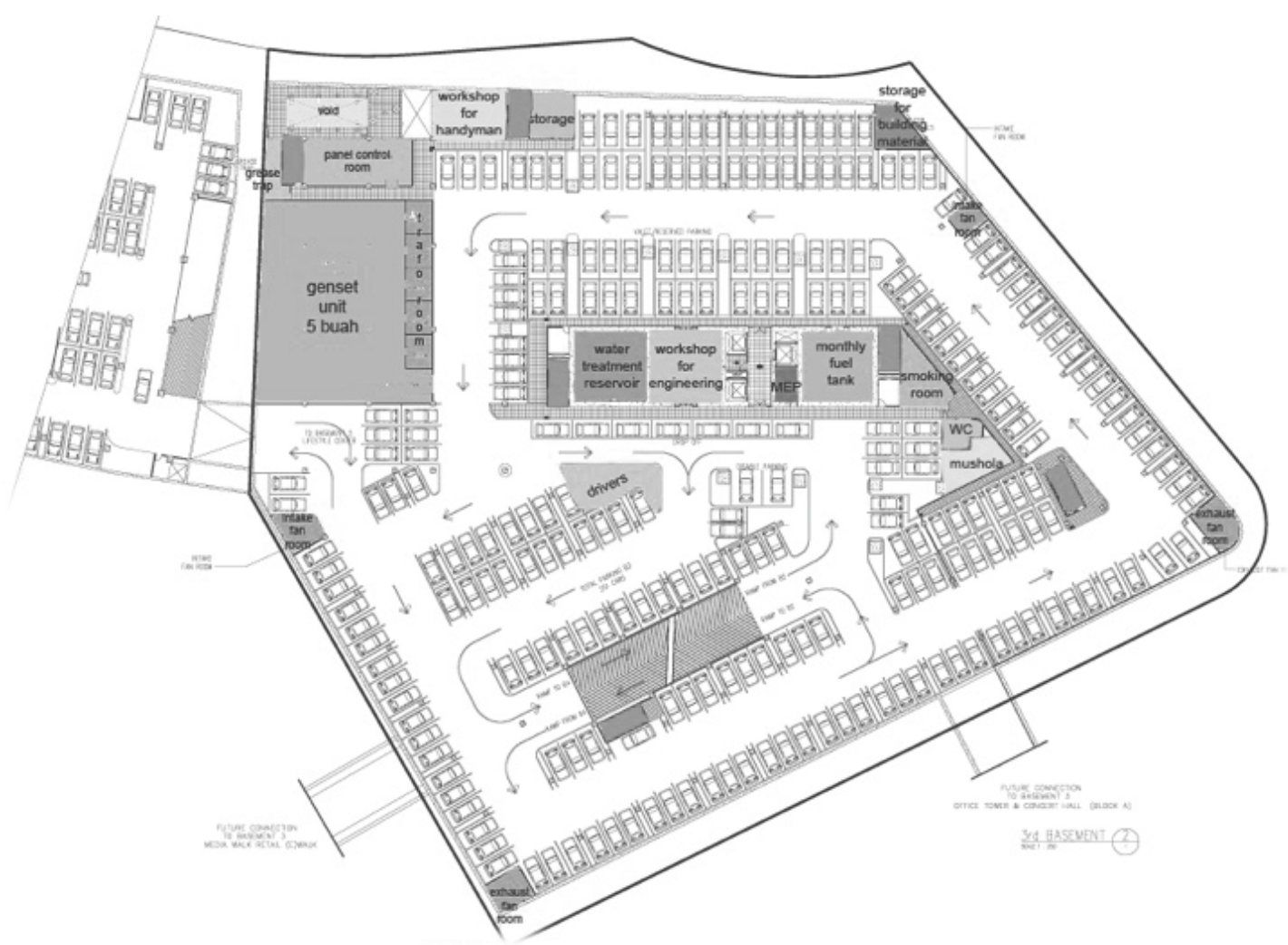

Gambar 3 Denah lantai basement 3 Bakrie Tower 


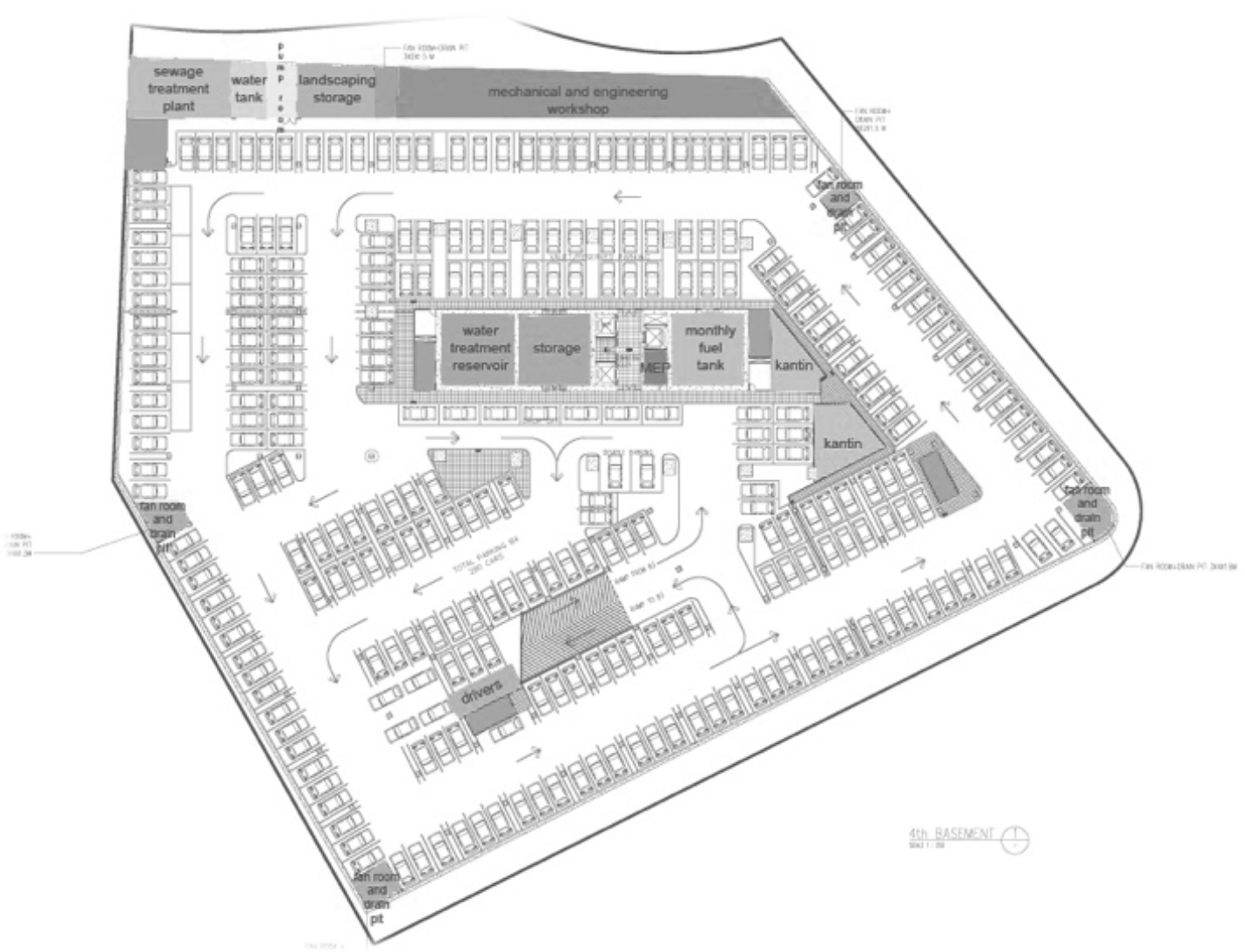

Gambar 4 Denah lantai basement 4 Bakrie Tower

Rincian total jumlah parkir dari ke 4 basement tersebut yaitu:

\begin{tabular}{lll} 
Basement & 1 & $=144$ parkir mobil. \\
Basement & 2 & $=245$ parkir mobil. \\
Basement & 3 & $=250$ parkir mobil. \\
Basement & 4 & $=297$ parkir mobil \\
\hline Total & & $=936$ parkir mobil.
\end{tabular}

Dilihat dari luas lantai sewa yang 59,404.96 $\mathrm{m}^{2}$ dengan jumlah kendaraan 936 mobil, didapat rasio parkir yaitu: 59.404,96 m2 : 936 mobil = 63,5 m2; atau setiap 63,5 m2 lantai sewa disediakan 1 parkir mobil.

\section{Studi Kasus Kebutuhan Parkir pada Tiara Marga Trakindo (TMT) Tower}

Lokasi

TMT Tower 1

TMT Tower 2

TMT Tower 1

Jumlah lantai

Total luas lantai

TMT Tower 2

Jumlah lantai

Total luas lantai

Total luas lantai lobby
: Jl. Cilandak KKO Raya BLD. 111

Jakarta Selatan

: 19 lantai kantor dan 2 basement.

: 3 lantai kantor dan 2 basement.

: luas lantai $=1.280 \mathrm{~m} 2$.

: 17 lantai

: $21.760 \mathrm{~m} 2$

: luas lantai $=1.185 \mathrm{~m} 2$.

: 5 lantai

$: 5.925 \mathrm{~m} 2$

: $380,5 \mathrm{~m} 2$

Total luas lantai TMT $1+$ TMT $2+$ lobby $=28.065 \mathrm{~m} 2$ 
Gambar 6 di bawah ini merupakan blok plan TMT Tower. Pada blok plan tersebut terlihat adanya parkir di tapak untuk kendaraan mobil.

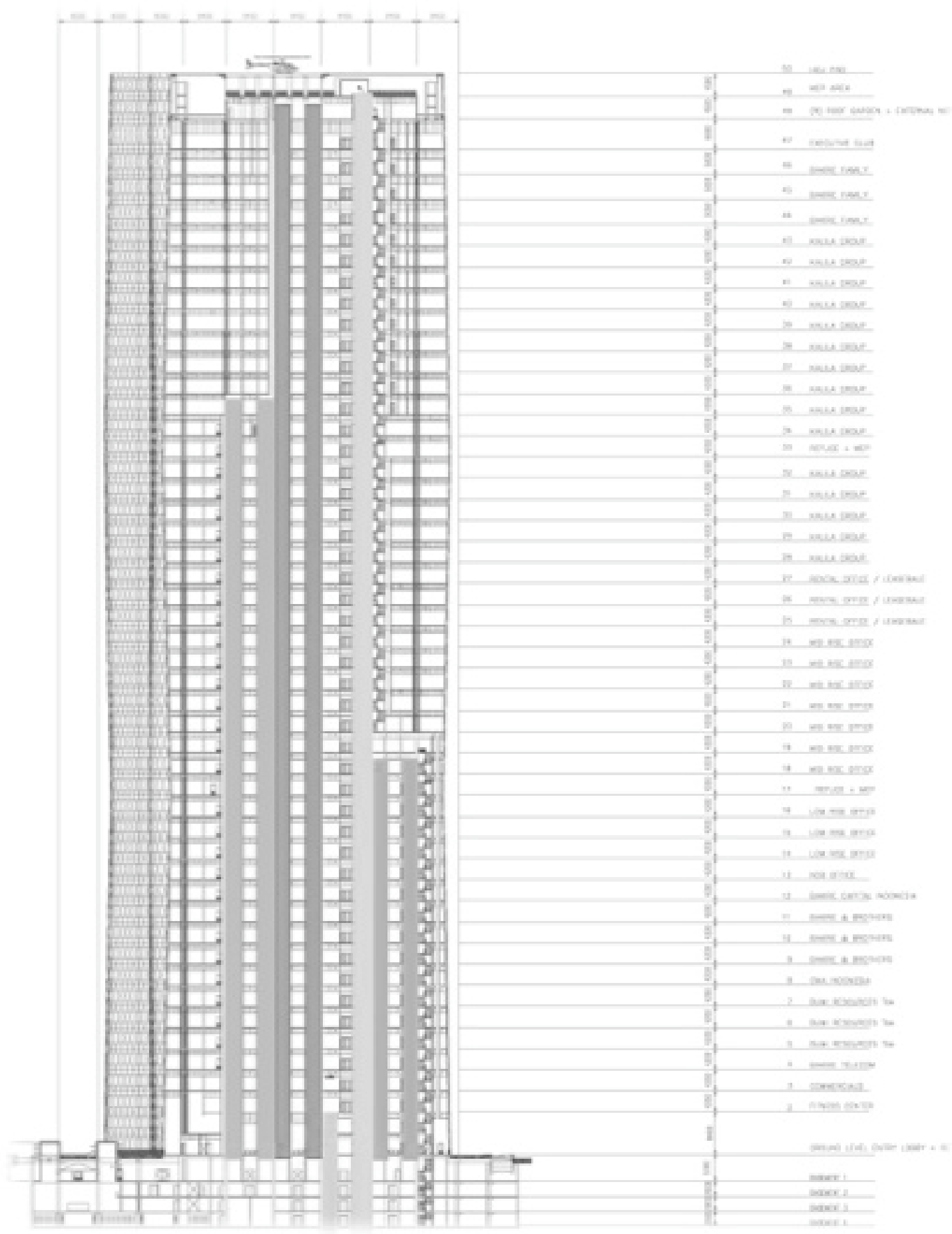

Gambar 5 Gambar potongan Bakrie Tower 


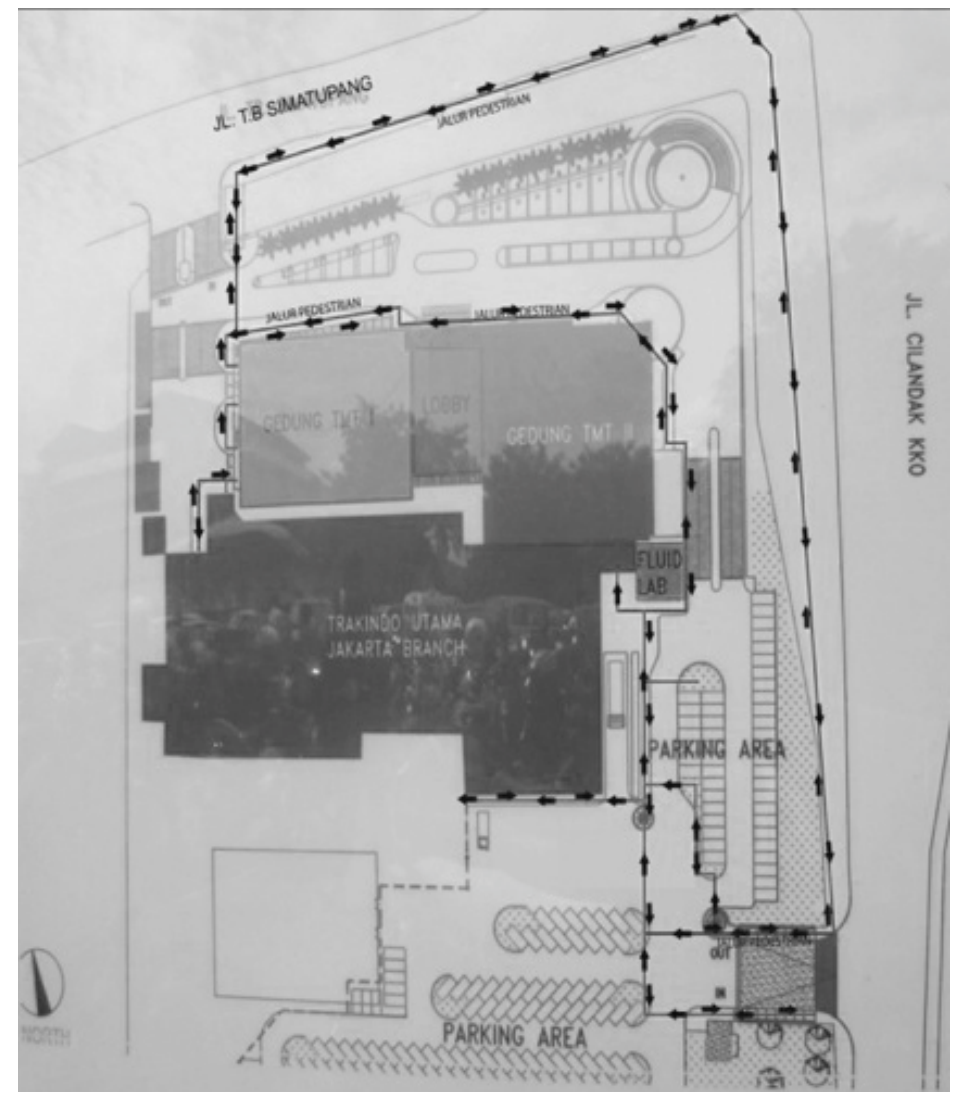

Gambar 6 Gambar blok plan TMT Tower

Pada denah basement 1 tower TMT 1 (Gambar 7) terlihat area untuk sirkulasi vertikal dan utilitas hanya 7\%, dengan total perincian luas lantai.

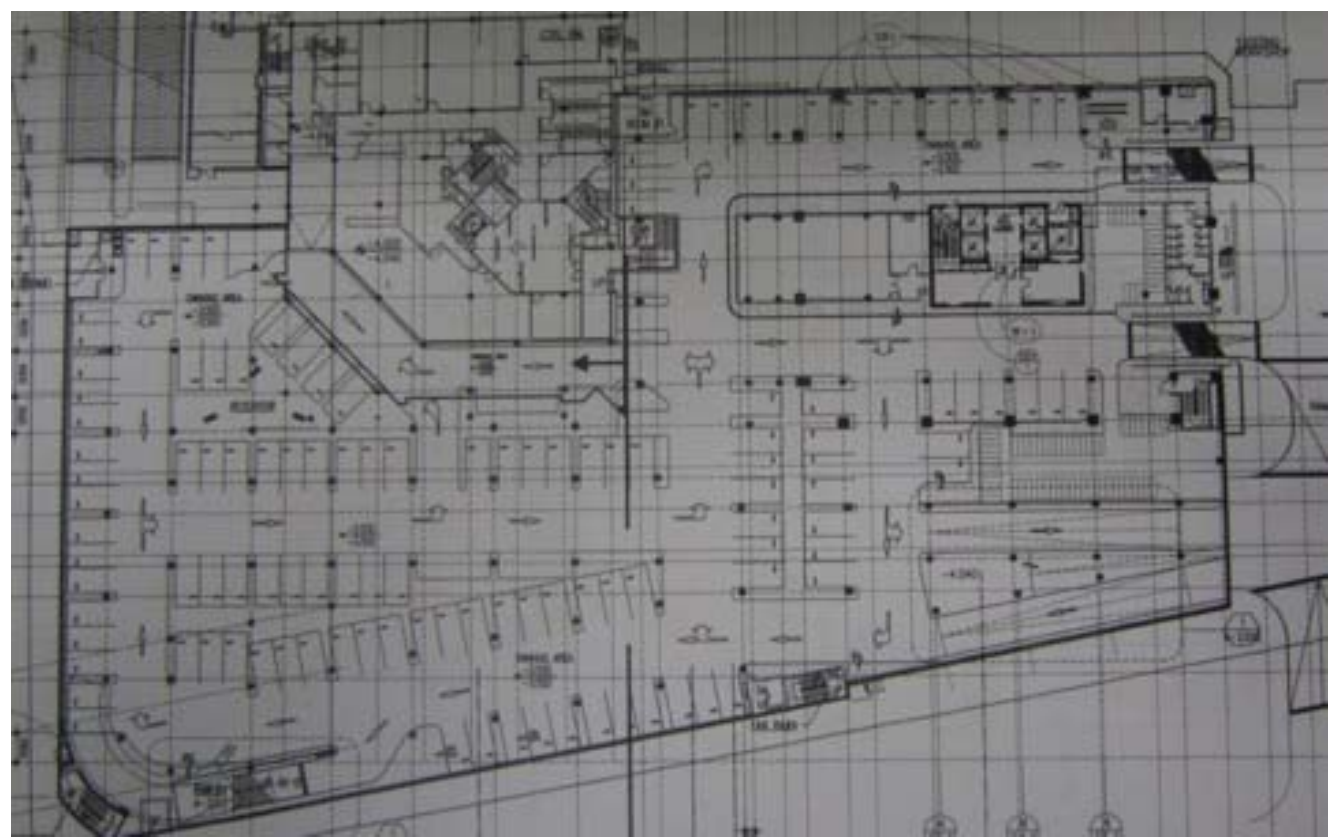

Gambar 7 Denah lantai basement 1 TMT Tower 
Pada denah basement 2 (Gambar 8) terlihat luas lantai untuk sirkualsi dan utilitas hanya tinggal kurang dari 3\% dari total luas lantai.

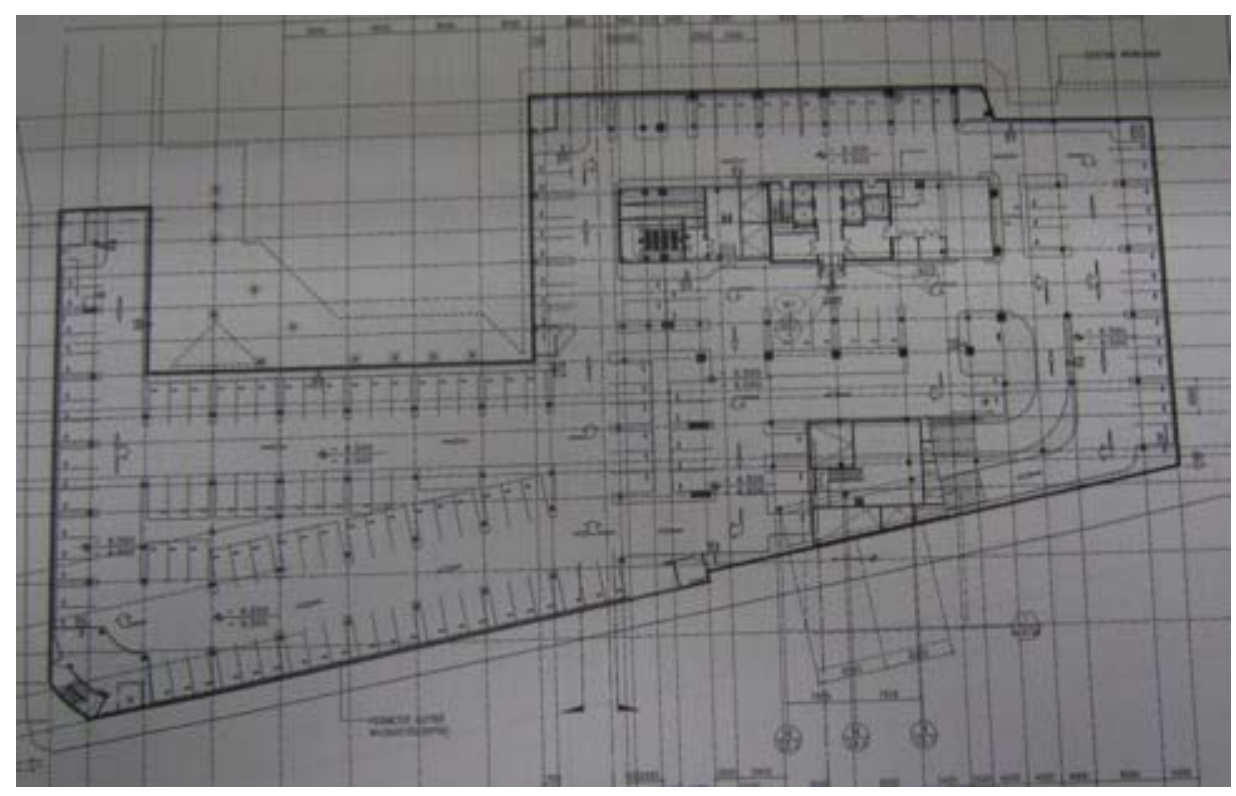

Gambar 8 Denah lantai basement 2 TMT Tower

Pada gambar 9 terlihat potongan melintang dari tower 1 dan 2 dengan penghubung lobby di tengah, dan basement yang menyambung untuk area parkir kendaraan.

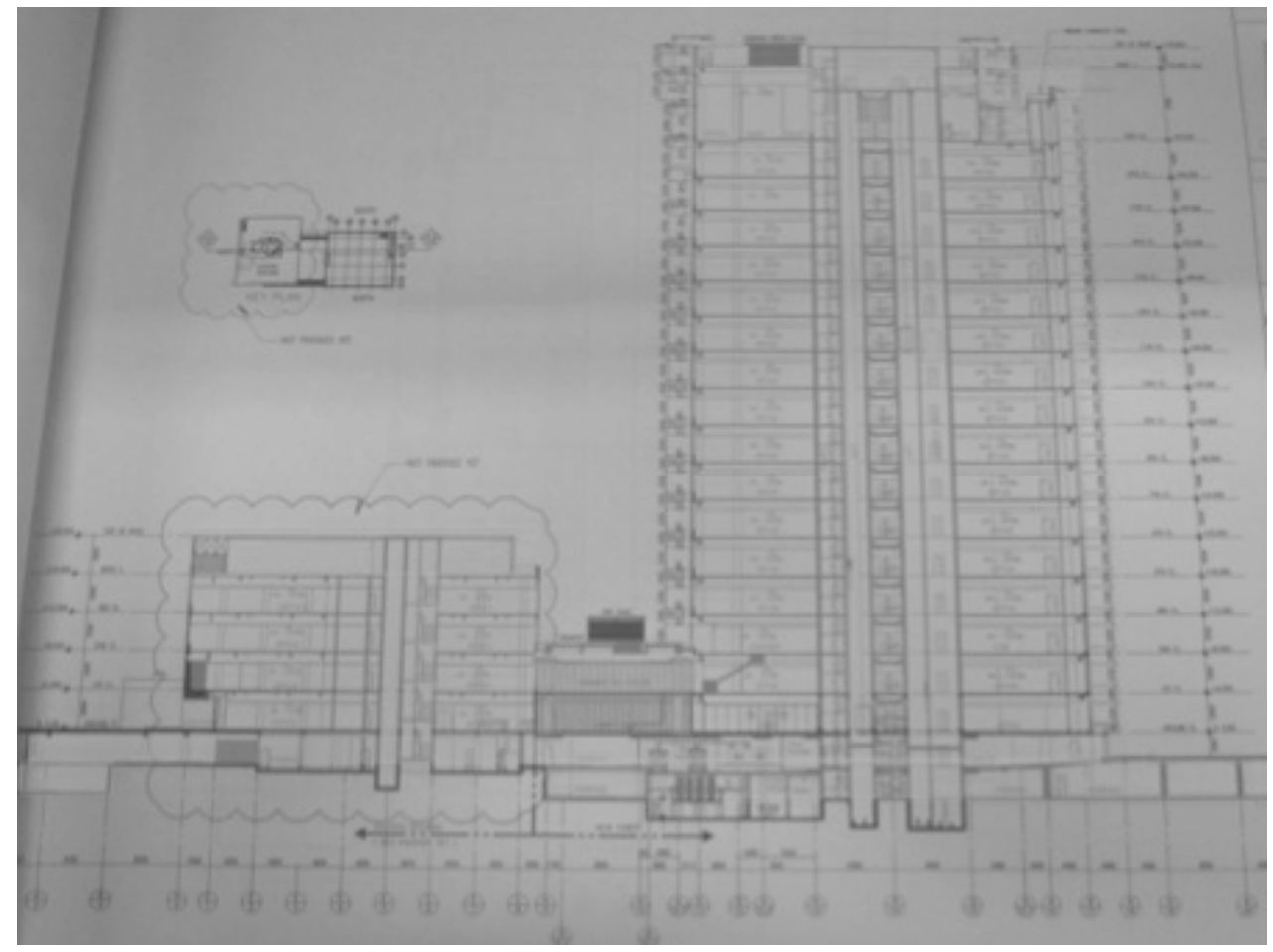

Gambar 9 Gambar potongan TMT Tower 
Perhitungan rasio parkir gedung ini yaitu:

Luas bangunan : $28.065 \mathrm{~m} 2$.

Luas lantai sewa $\quad: 23.855 \mathrm{~m} 2$

Jumlah parkir tersedia : 440 parkir mobil.

Rasio parker $\quad:$ 23.855:440 mobil $=54,21 \mathrm{~m} 2$, atau setiap 54,21 $\mathrm{m} 2$ lantai bangunan tersedia

1 parkir mobil.

\section{Studi Kasus Kebutuhan Parkir pada Wisma 77}

\section{Lokasi}

Luas lantai bangunan

Jumlah lantai

Total luas lantai bangunan

Total luas lantai sewa bangunan

Total lantai parkir

\author{
: Jl. LetJen S. Parman kav 77 \\ Jakarta Barat \\ : $1.232 \mathrm{~m} 2$. \\ : 17 lantai. \\ : $20.944 \mathrm{~m} 2$. \\ : $17.593 \mathrm{~m} 2$. \\ : 1 basement +7 gedung parkir
}

Gambar 10 merupakan denah parkir basement Wisma 77. Terlihat total parkir dapat menampung 41 kendaraan mobil. Sistem parkir yang digunakan antara basement 1 dan basement 1 A adalah sistem split level, dengan sebagian pada area basement ini digunakan untuk ruangan penunjang seperti ruang keamanan, ruang tunggu sopir, ruang penyimpanan barang, ruang kebersihan, area lift untuk menghubungkan ke lantai atas, serta area lobby untuk masuk ke gedung perkantoran utama.

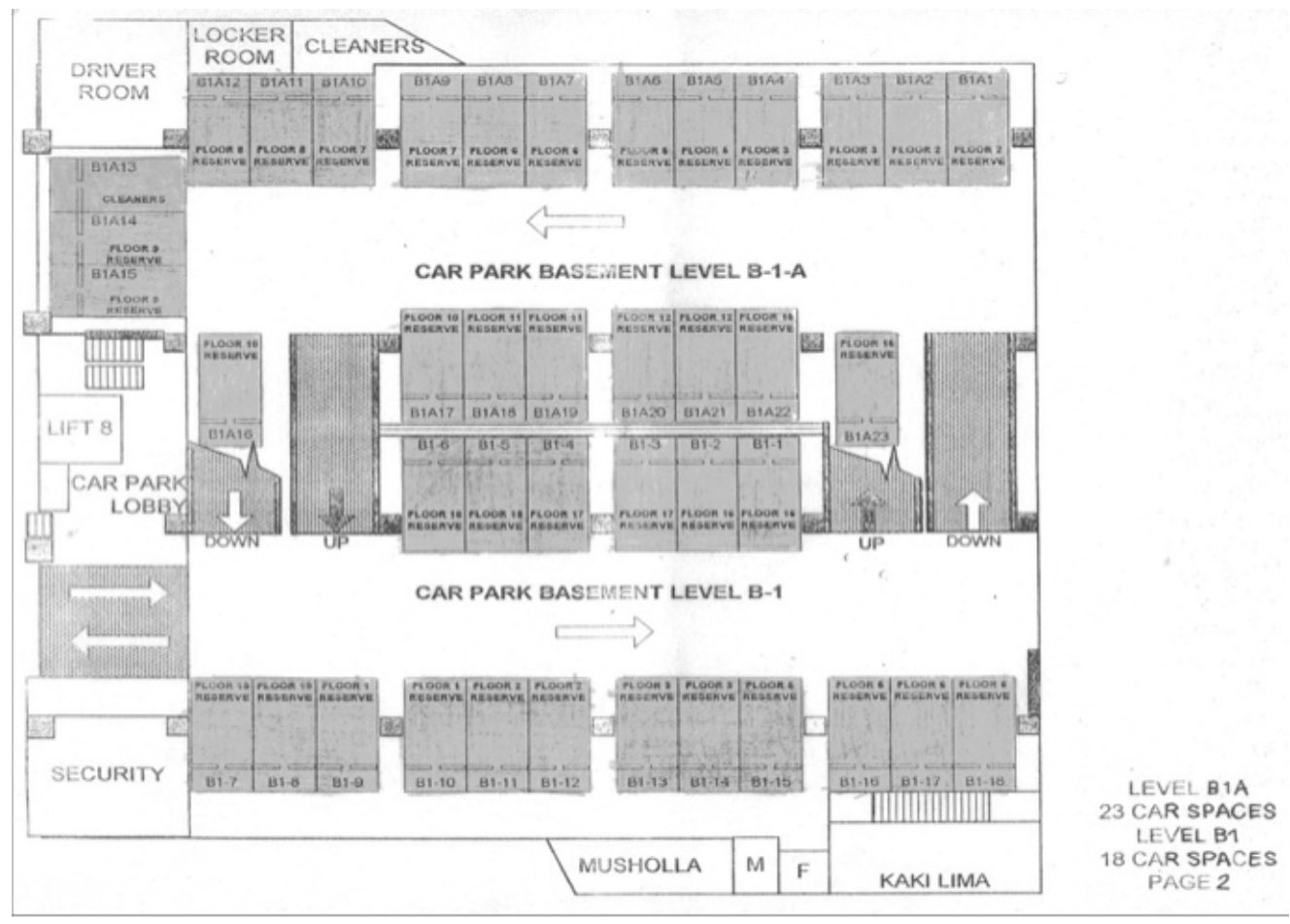

Gambar 10 Denah lantai basement Wisma 77

Gambar 11 merupakan denah parkir lantai 1. Ketersediaan jumlah parkir mobil 30 buah, dan total parkir motor 24 buah. 


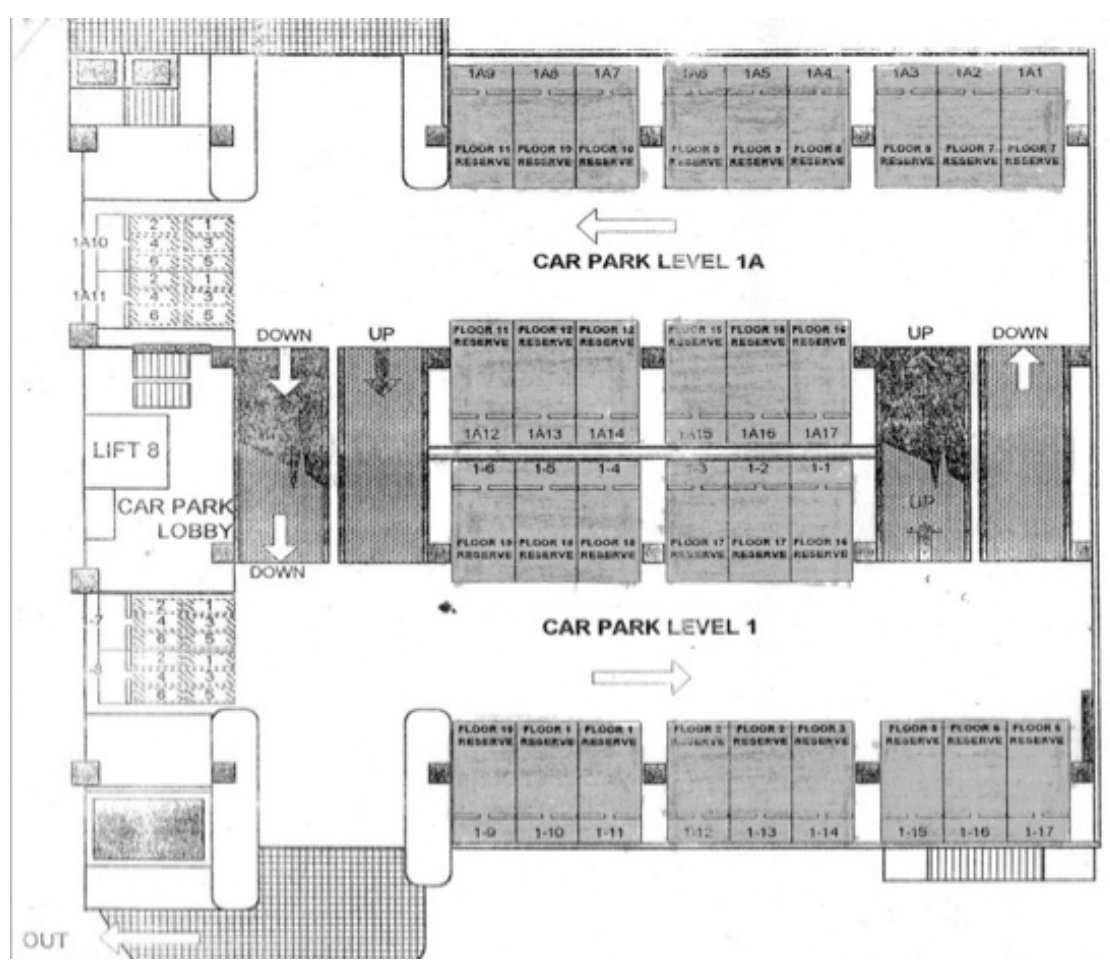
15 CAR SPACES 12 MOTORCYCLES LEVEL 1 15 CAR SPACES 12 MOTORCYCLE 8

LEVEL 1 A

Gambar 11 Denah lantai 1 gedung parkir Wisma 77

Gambar 12 merupakan denah parkir lantai 2. Ketersediaan jumlah parkir mobil 36 buah, dan total parkir motor 32 buah.

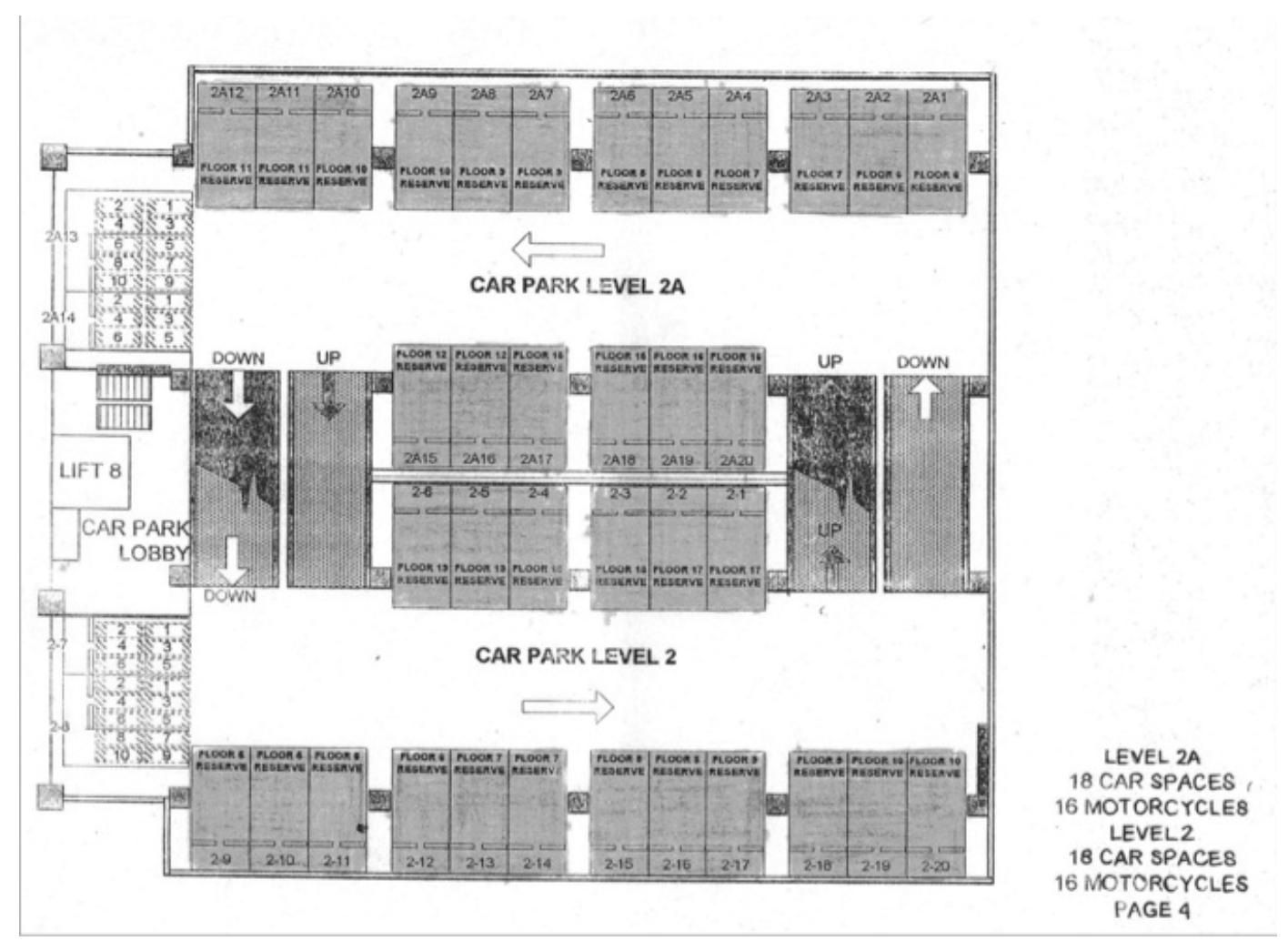

Gambar 12 Denah lantai 2 gedung parkir Wisma 77 
Gambar 13 adalah denah parkir lantai 3. Ketersediaan jumlah parkir mobil 36 buah, dan total parkir motor 32 buah. Wisma 77 tidak memiliki lantai 4. Untuk denah parkir lantai 5 (Gambar 14), lantai 6 (Gambar 15) dan lantai 7 (Gambar 16) ketersediaan jumlah parkir mobil ada 40 buah. Sedangkan untuk lantai 8, ketersediaan jumlah parkir mobil ada 36 buah.

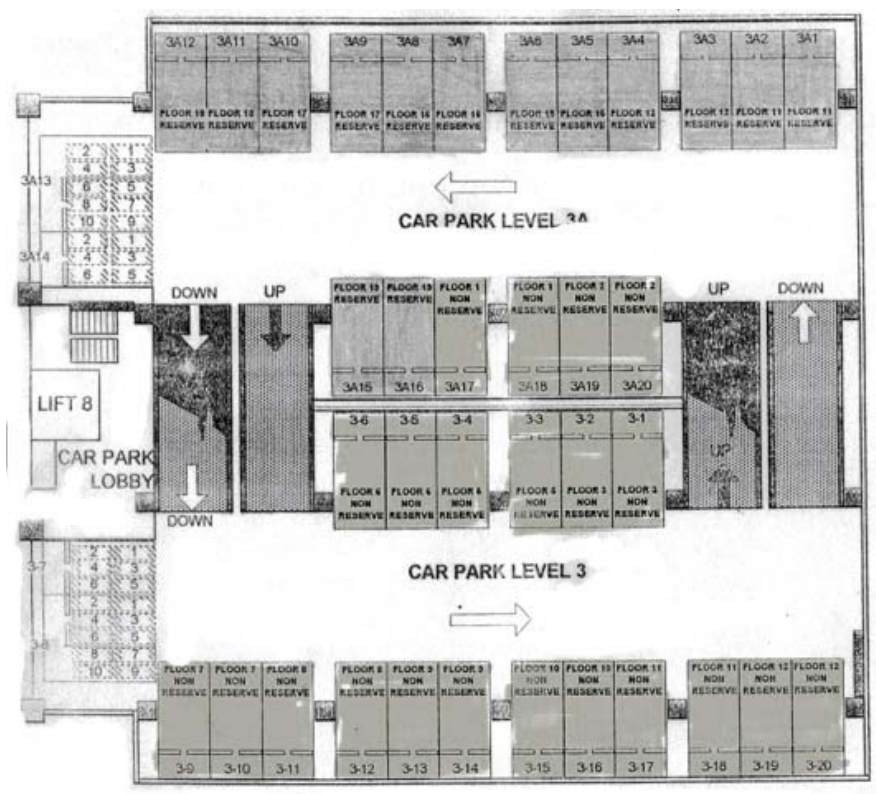

Gambar 13 Denah lantai 3 gedung parkir Wisma 77

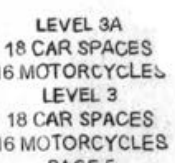

16 MOTORCYCLES

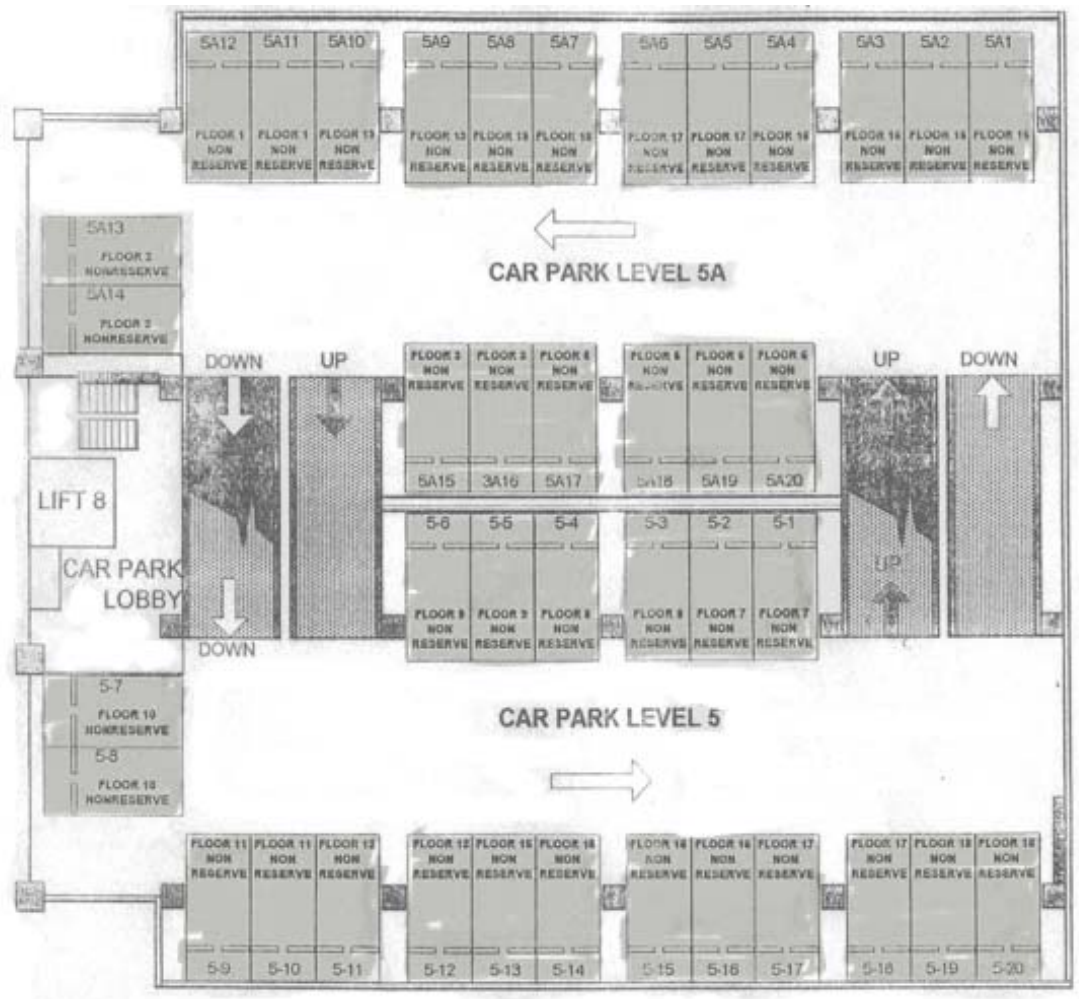

LEVEL 5 A 20 CAR SPACES

LEVEL 5 20 CAR SPACES PAGE 6

Gambar 14 Denah lantai 5 gedung parkir Wisma 77 


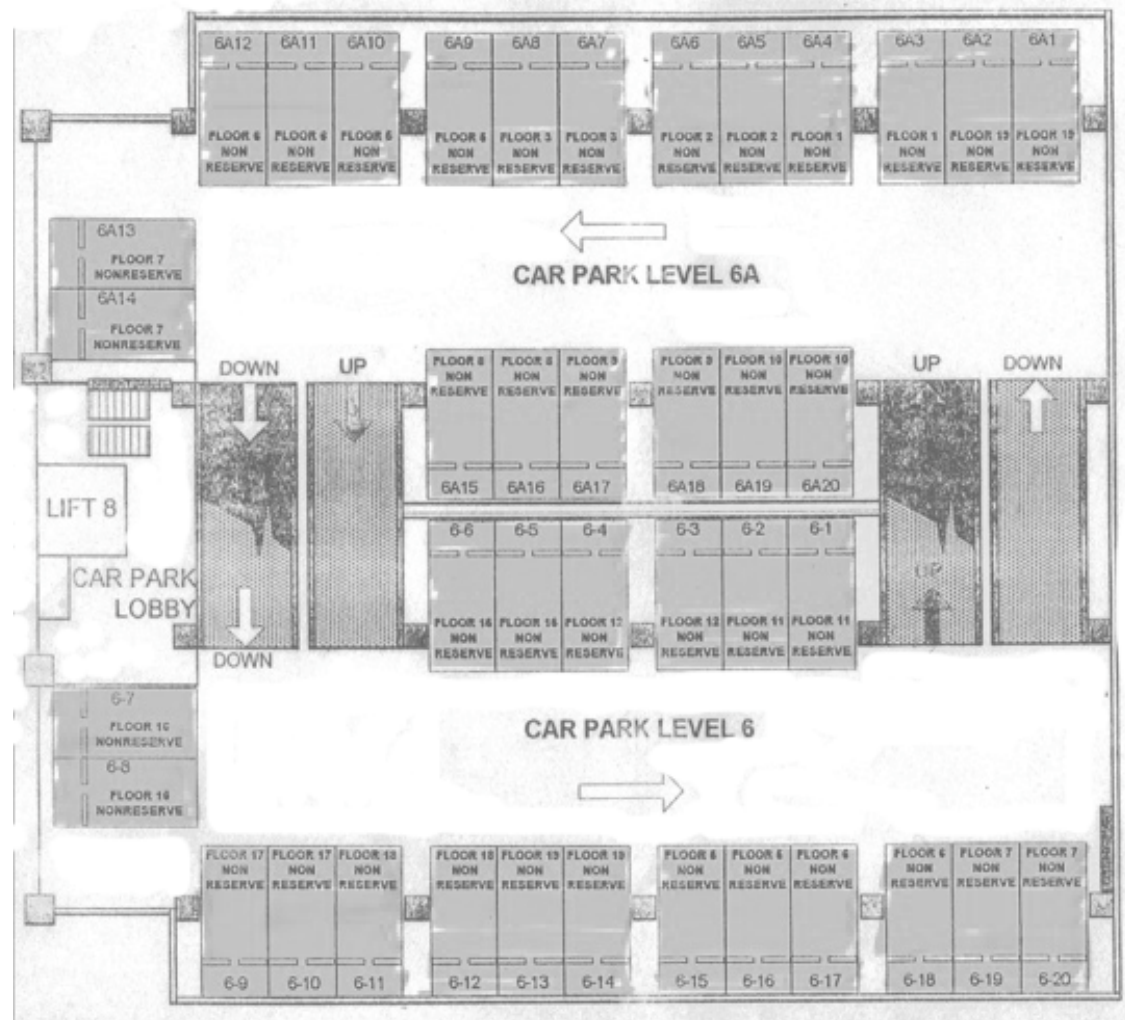

Gambar 15 Denah lantai 6 gedung parkir Wisma 77

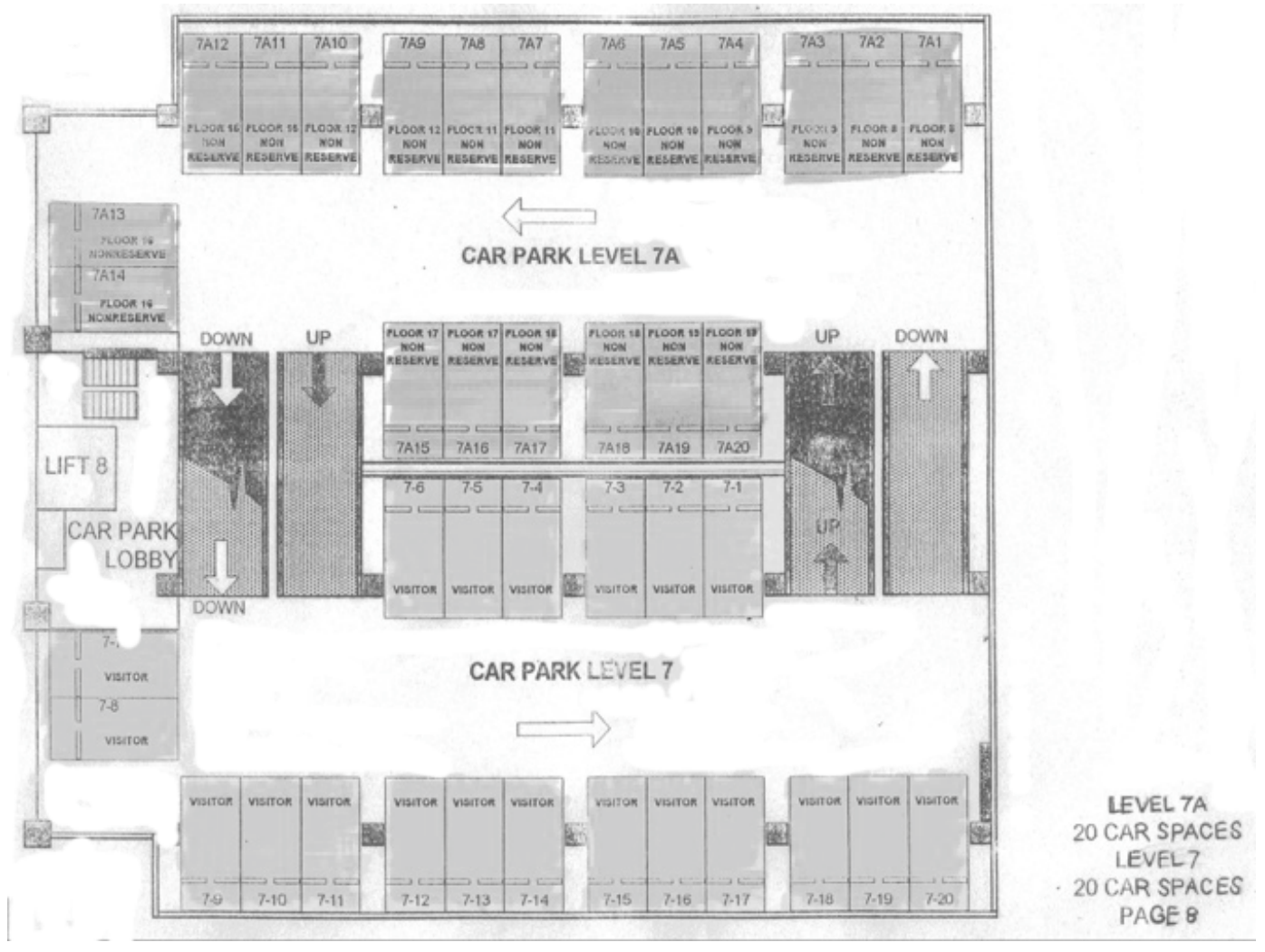

Gambar 16 Denah lantai 7 gedung parkir Wisma 77 


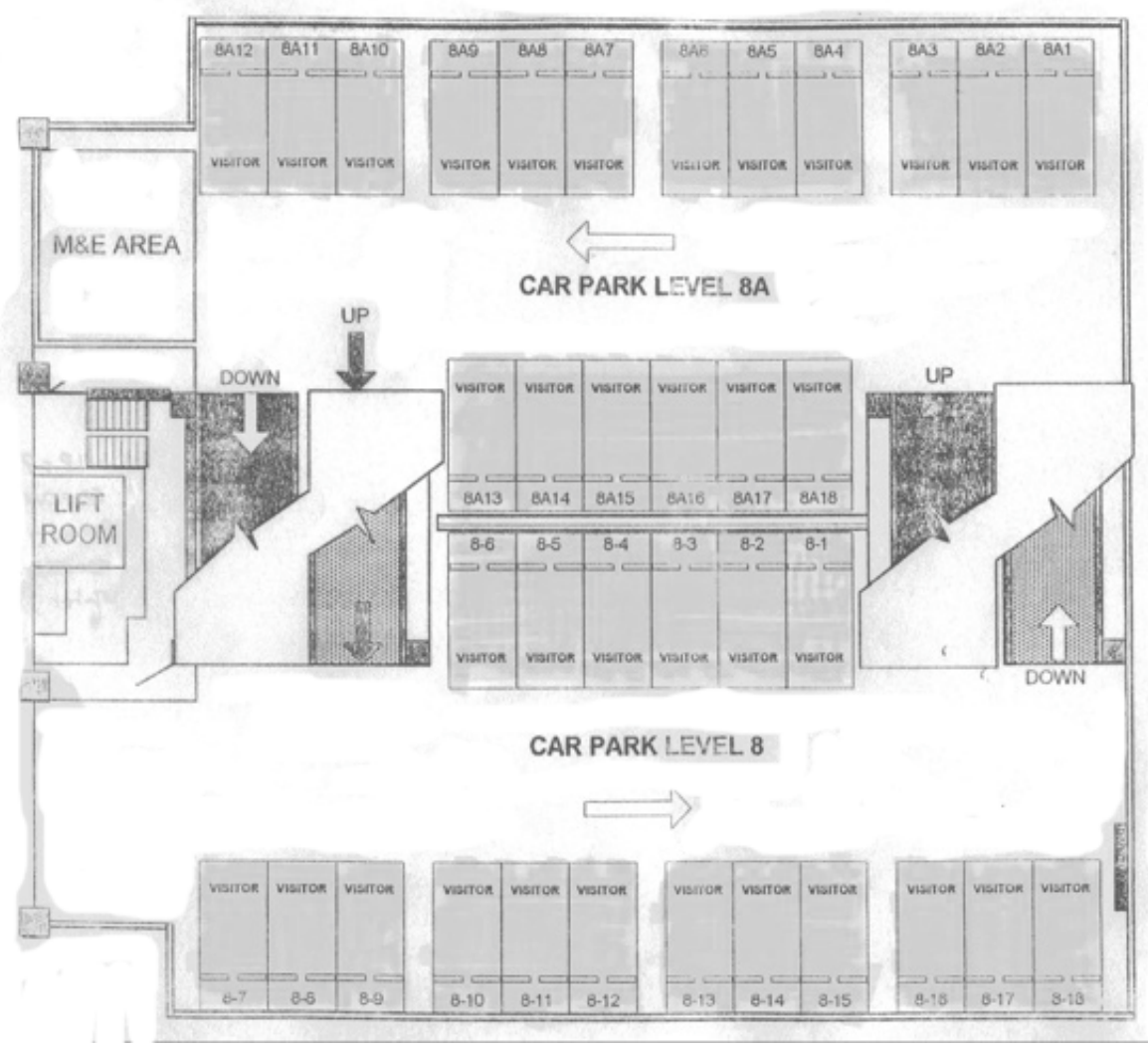

Gambar 17 Denah lantai 8 gedung parkir Wisma 77

$\begin{array}{lc}\text { Rangkuman total ketersediaan jumlah parkir mobil yaitu: } \\ \text { Lantai basement } & 41 \text { mobil } \\ \text { Lantai } 1 & 30 \text { mobil } \\ \text { Lantai } 2 & 36 \text { mobil } \\ \text { Lantai 3 } & 36 \text { mobil } \\ \text { Lantai 5 } & 40 \text { mobil } \\ \text { Lantai 6 } & 40 \text { mobil } \\ \text { Lantai } 7 & 40 \text { mobil } \\ \text { Lantai } 8 & 36 \text { mobil } \\ \text { Total jumlah parkir mobil } & 299 \text { mobil }\end{array}$

Dari data di atas, rasio parkir untuk gedung Wisma 77 yaitu: $17.593 \mathrm{~m} 2: 299$ mobil = 58,84 m2.

Pada gambar 18, terlihat bagaimana posisi gedung parkir terhadap gedung utama perkantoran sewa, yaitu gedung parkir berada berimpit di belakang bangunan gedung perkantoran sewa, dengan jumlah lantai parkir total adalah 8 lantai. Dengan cara seperti itu mempermudah dan mempercepat akses pengunjung dari setiap lantai parkir ke area gedung perkantoran. 


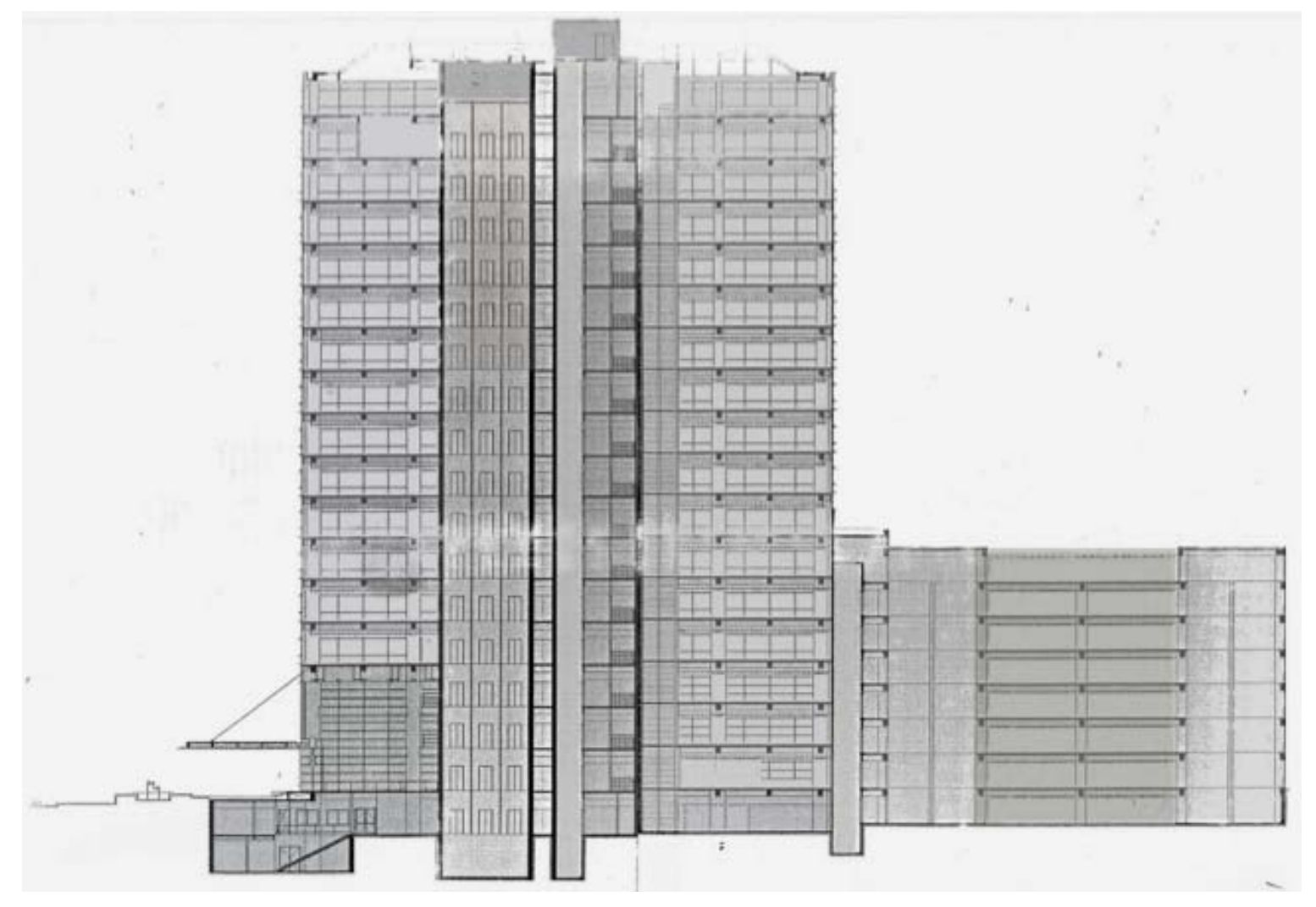

Gambar 18 Gambar potongan gedung parkir Wisma 77

Dari 3 data perkantoran swasta yang ada, diperoleh rasio dari setiap gedung dengan hasil sebagai berikut: (1) Bakrie Tower, Jakarta Pusat, mempunyai rasio parkir 1 mobil untuk setiap 63,5 m2 lantai sewa; (2) TMT Tower, Kakarta Selatan, mempunyai rasio parkir 1 mobil untuk setiap 54,21 m2 lantai sewa; (3) Wisma 77, Jakarta Barat, mempunyai rasio parkir 1 mobil untuk setiap 58,84 m2 lantai sewa.

\section{PENUTUP}

Berdasarkan rasio parker, yaitu penyediaan 1 parkir mobil untuk setiap 54,21 - 63,5 m2, terbukti bahwa perkantoran swasta di Jakarta masih belum dapat memenuhi kebutuhan luas parkirnya. Hal ini dapat dibuktikan dari sulitnya mendapatkan parkir di area yang sudah ditentukan, sehingga kendaraan harus parkir secara parallel menutupi kendaraan yang parkir di salah 1 sisi jalan.

Di luar negeri, pada negara maju seperti Singapura, Amerika, Eropa, Australia, rasio parkirnya adalah 1 parkir mobil untuk setiap $100 \mathrm{~m} 2$ lantai sewa, dan ini masih mencukupi, karena transportasi kota sudah memadai, sehingga para karyawan golongan ekonomi menengah ke atas, ataupun karyawan dengan jabatan manajer ke atas mau untuk menggunakan kendaraan umum yang ada.

Berdasarkan hasil tersebut, penulis mengusulkan agar rasio standar parkir gedung perkantoran di Jakarta ditentukan untuk setiap 1 parkir mobil adalah untuk luas lantai sewa maksimal $50 \mathrm{~m} 2$. Hal tersebut diakibatkan oleh jumlah ketersediaan parkirmobil sangat tidak mencukupi, baik itu untuk parkir kendaraan penyewa gedung perkantoran, ataupun untuk tamu yang datang ke gedung perkantoran itu sendiri. 


\section{DAFTAR PUSTAKA}

Birk, Mia Layn dan Zegras, P. Christopher. (1993). Moving Toward Integrated Transport Planning: Energy, Environment, and Mobility in Four Asian Cities. Singapore: International Institute for Energy Conservation.

Chick, Colin. (1996). On-Street Parking - A Guide to Practice. London: Landor Publishing.

Ernest and Neufert, Peter. (2002). Architect Data ( $3^{\text {rd }}$ edition). Oxford: The Alden Group.

Hill, J. D, Shenton, D. C. and Jarrold, A. J. (1990). Multi-Strorey Car Parks. London: Landor Publishing.

O’Flaherty, C. A. (1997). Transport Planning and Traffic Engineering (4 ${ }^{\text {th }}$ edition). Edmonton: Arnold Publishing. 